\title{
Modifications to the nutrition for sport knowledge questionnaire (NSQK) and abridged nutrition for sport knowledge questionnaire (ANSKQ)
}

\author{
Gina Louise Trakman ${ }^{1 *}$ (D) Freddy Brown ${ }^{2,4}$, Adrienne Forsyth ${ }^{1}$ and Regina Belski ${ }^{3}$
}

\begin{abstract}
New evidence and feedback from colleagues have led to modifications to the Nutrition for Sport Knowledge Questionnaire (NSKQ) and Abridged Nutrition for Sport Knowledge Questionnaire (ANSKQ). The changes predominately affect questions regarding the nutrient content of foods, protein recommendations and the legality of supplements. Some English language edits have also been made.
\end{abstract}

Keywords: Athlete, Nutrition knowledge, Questionnaire

\section{Main text}

In 2015-2017 Trakman et al. developed the Nutrition for Sport Knowledge Questionnaire (NSKQ) [1] and the Abridged Nutrition for Sport Knowledge Questionnaire (ANSKQ) [2]. The NSKQ and ANSKQ been used to assess Australian athletes' nutrition knowledge [2-4]. The authors have received over 135 requests from researchers and professionals interested in utilising the tools. International researchers have translated the NSKQ into German, Italian, Swedish, Turkish, Chinese and Malay. Since the development of the NSKQ and ANSKQ, the International Society of Sports Nutrition (ISSN) published new consensus recommendations on protein [5, 6] and World Anti-Doping Agency (WADA) changed the legality of glycerol [7]. Moreover, administration of the tool and feedback from colleagues (in particular, Freddy Brown) has led to reflections regarding areas for improvement. The key changes are outlined below. Item numbers refer to the NSKQ and where relevant, these changes have also been applied to the ANSKQ.

Items modified due to lack of clarity:

\footnotetext{
* Correspondence: G.trakman@latrobe.edu.au

${ }^{1}$ Department of Rehabilitation, Nutrition and Sport, School of Allied Health, College of Science, Health and Engineering, La Trobe University, Melbourne 3086, Australia
}

Full list of author information is available at the end of the article
- Item 2.5 on high/low fat foods was based on The Australian Dietary Guidelines, which recommend patients choose foods with less than $10 \%$ fat (or 15\% for cheese). However, in most countries, labelling laws $[8,9]$ state that foods can only be classed as low fat if they have less than 3\% fat. Thus, classing foods such as cottage cheese (fat content approximately $1-8 \%$ ) as low fat could be confusing. We replaced 'cottage cheese' with 'cheddar cheese' and changed the correct answer from 'low fat' to 'high fat'. This allows for more consistent interpretation because cheddar cheese (even when reduced fat) has more than $3 \mathrm{~g}$ of fat per $100 \mathrm{~g}$. Since correct options are based on \% (per $100 \mathrm{~g}$ of the food), we also omitted portions from response options. This is Q2.5.1 in the NSKQ and Q3 in the ANSKQ.

- Item 2.2 on high/low carbohydrate foods was adapted from existing questionnaires. The correct answers had at least $20 \mathrm{~g}$ of carbohydrate, which is about the amount of carbohydrate in a 'serving' of grain foods [10]. However, the correct answers did not factor in definitions for 'high carbohydrate' stated by on European Food Safety Authority (EFSA)/Food Standards Australia New Zealand (FSANZ) [8, 9] ('not less than 90 $\%$ of average energy derived as carbohydrate and more than $15 \%$ by weight is carbohydrate'). Twenty grams of 
carbohydrate is a small amount in absolute terms. Therefore, item 2.2 has been modified from 'Do you think these foods are high/low in carbohydrate' to 'Which of these foods would provide enough carbohydrate for a recovery from about 1 hour of high intensity aerobic exercise? Assume the athlete weighs about $70 \mathrm{~kg}$ and has an important training session again tomorrow'. The correct options have been adjusted accordingly. These are Q12, 13 in the ANSKQ.

- Item 2.9 on high/low protein foods was adapted from existing questionnaires. Quinoa was included as an incorrect option because although this grain is relatively high in protein compared to other grains, its absolute protein content is still quite low. In most countries foods can be classified as a good source of protein if they have at least $10 \mathrm{~g}$ of protein per serving or as 'high' in protein if at least $20 \%$ of energy content is protein $[8,9]$. Item 2.9 was modified to ask if foods contain enough protein to promote muscle growth after a bout of resistance exercise (with $>20 \mathrm{~g}$ being considered an acceptable dose of protein). These are Q14, 15, 16 in the ANSKQ.

- Item 2.6.4 previously stated 'protein absorption in a single sitting is limited'. Here, we were referring to the ability of the body to synthesise muscle from ingested protein. To clarify this, the statement was modified to 'The body has a limited ability to use protein for muscle synthesis'. This is Q6 in the ANSKQ.

- Item 3.2 asked about 'best sources' of micronutrients. Best is a comparative term and depends on whether you are referring to the amount of nutrient per $100 \mathrm{~g}$ or per serving. Therefore, these items were modified to ask if the foods were 'good sources' of each nutrient.

Correct answers were based on EFSA/ FSANZ criteria, which state that for a food to be considered a 'good' source, it must meet $30 \%$ of the Recommended Dietary Intake (RDI) $[8,9]$. These are now Q3.1.6 to 3.1.8 in the NSKQ and are not included in the ANSKQ.

- Item 3.3.5 Athletes have increased magnesium losses in sweat' was deleted due to a lack of consensus.

- Item 4.3 on optimal carbohydrate concentration for hydration purposes (i.e. in sports drink) was omitted because this is a confusing issue. Carbohydrate supports performance, not hydration; at low concentrations $(\sim 3 \%)$ absorption and retention is likely similar or mildly better than water. At higher concentrations (e.g. 8\%) fluid absorption and retention may be impaired.

- Item $\mathbf{5 . 5}$ was on supplements that are supported for 'improving sporting performance'. Leucine may have positive effects on muscle synthesis but not necessarily performance per se. This question was re-worded to ask which supplements were proven in relation to 'improving sporting performance and/or body composition'. This is Q34 in the ANSKQ.

Items modified due to change in evidence/emerging themes

- Due to the prevalence of Vitamin D deficiency, the item 3.1.5 'Vitamin D enhances calcium absorption' was added and item 3.2.4 'Fatty fish is a good source of Vitamin D' replaced 'Milk, yoghurt and Cheese are the best sources of magnesium'. These questions are not included in the ANSKQ.

- ISSN consensus statement recommends 1.4-2.0 g protein $/ \mathrm{kg} /$ day. For item $\mathbf{2 . 7}$ on protein needs of well-trained athletes, the correct option was changed from $130 \mathrm{~g}$ to $150 \mathrm{~g}$, to reflect higher recommendations. Also, $250 \mathrm{~g}$ was deleted as an 'incorrect answer', given evidence supporting potential benefits of very high protein intakes $(2.3-3.1 \mathrm{~g} / \mathrm{kg})$ for retention of lean muscle mass for athletes on hypocaloric diets [6]. This is Q21 in the ANSKQ.

- For Item 5.6 the correct option for banned substances was changed from 'glycerol' to 'testosterone'. This is Q35 in the ANSQ.

Re-wording of several items has also been undertaken to make language simpler. For example:

- Item 1.2.2 was re-worded from 'Increasing protein in the diet is the main dietary change needed when only muscle gain is desired' to 'Eating more protein is the most important dietary change if you want to have more muscle. This is Q17 in the ANSKQ.

- Item 6.5.2 was re-worded from 'Drinking large amounts of alcohol can reduce recovery from injury' to 'Drinking lots of alcohol can make it harder to recover from injury'. This question is not included in the ANSKQ.

- A copy of the new tools are available from Dr. Gina Trakman (g.trakman@latrobe.edu.au)

- The Italian ANSKQ can be obtain from: Umberto Placentino (uplacentino@gmail.com). For additional work on the tools in Italian contact Michele Gobbi and Roberto Cattivelli (michelegobbi93@icloud.com; roberto79cattivelli@gmail.com)

- The Swedish NSKQ can be obtained from: Lilja Guðmundsdóttir (lig31@hi.is)

- The Turkish NSKQ can be obtained from: Onur Çirak (ocirak@ankara.edu.tr)

- The Chinese NSKQ can be obtained from: Jackie Shao (utaipei101@gmail.com) 
- The Malay NSKQ can be obtained from: Norashikin Binti Mustafa (p95560@siswa.ukm.edu.my)

- Details on the German NSKQ will be available shortly.

Many thanks,

Gina Trakman, Freddy Brown, Adrienne Forsyth and Regina Belski.

\section{Abbreviations}

ANSKQ: Abridged nutrition for sport knowledge questionnaire:

EFSA: European Food on European Food Safety Authority; FSANZ: Food Standards Australia New Zealand; ISSN: International society of sports nutrition; NSKQ: Nutrition for sport knowledge questionnaire; WADA: World Anti-Doping Agency

\section{Acknowledgements}

The authors thank fellow researchers and collaborates for their interest in the NSKQ and ANSKQ, and contribution to research on Nutrition Knowledge of athletes.

\section{Authors' contributions}

GT made final decisions regarding questionnaire modifications and drafted the manuscript. FB proposed several changes to improve question items and assisted with manuscript preparation. AF assisted decision making regarding modifications to the questionnaire and assisted with manuscript preparation. RB assisted decision making regarding modifications to the questionnaire and assisted with manuscript preparation. All authors read and approved the final manuscript.

\section{Funding}

The authors have no funding to declare.

\section{Availability of data and materials}

The data used/and or analyses during the current study are available from the corresponding author on reasonable request.

\section{Ethics approval and consent to participate}

The original research was approved (S16/267) by the La Trobe University's SHE College Human Ethics Sub-Committee (SHE CHESC). Participants read the Participant Information Statement and provided consent electronically.

\section{Consent for publication}

No individual's data has been collected or reported.

\section{Competing interests}

The authors declare that they have no competing interests.

\section{Author details}

'Department of Rehabilitation, Nutrition and Sport, School of Allied Health, College of Science, Health and Engineering, La Trobe University, Melbourne 3086, Australia. ${ }^{2}$ Faculty of health and life sciences, Coventry University, Coventry, England CV1 2TU, UK. ${ }^{3}$ Department of Health Professions, School of Health Sciences, Faculty of Health, Arts and Design, Swinburne University of Technology, Hawthorn 3122, Australia. ${ }^{4}$ English Institute of Sport, The Manchester Institute of Health and Performance, Manchester M11 3BS, UK.

Received: 24 April 2019 Accepted: 19 June 2019

Published online: 28 June 2019

\section{References}

1. Trakman GL, Forsyth A, Hoye R, Belski R. The nutrition for sport knowledge questionnaire (NSKQ): development and validation using classical test theory and Rasch analysis. J Int Soc Sports Nutr. 2017;14(1):26-36.

2. Trakman GL, Forsyth A, Hoye R, Belski R. Development and validation of a brief general and sports nutrition knowledge questionnaire and assessment of athletes' nutrition knowledge. J Int Soc Sports Nutr. 2018;15:17-22.
3. Trakman GL, Forsyth A, Middleton K, Hoye R, Jenner S, Keenan S, et al. Australian football athletes lack awareness of current sport nutrition guidelines. Int J Sport Nutr Exerc Metab. 2018;28:644-50.

4. Jenner SL, Trakman G, Coutts A, Kempton T, Ryan S, Forsyth A, et al. Dietary intake of professional Australian football athletes surrounding body composition assessment. J Int Soc Sports Nutr. 2018;15:43-50.

5. Jäger R, Kerksick CM, Campbell BI, Cribb PJ, Wells SD, Skwiat TM, et al. International society of sports nutrition position stand: protein and exercise. Int Soc Sports Nutr. 2017;14(1):20.

6. Hector AJ, Phillips SM. Protein recommendations for weight loss in elite athletes: A focus on body composition and performance. Int J Sport Nutr Exerc Metab. 2018;28(2):170-7.

7. WADA. Summary of major modifications and explanatory notes: World Antidoping Agency (WADA); 2018 [Available from: https://www.wada-ama.org/ sites/default/files/prohibited list 2018 summary of modifications en.pdf

8. FSANZ. Getting Your Claims Right 2018 [Available from: http://www. foodstandards.gov.au/publications/Pages/gettingyourclaimsright.aspx.

9. EFSA. EU Register of nutrition and health claims made on foods 2016 [Available from: http://ec.europa.eu/food/safety/labelling_nutrition/claims/ register/public/?event=register.home.

10. NHMRC. Australian dietary guidelines 2015 [available from: https://www eatforhealth.gov.au/.

\section{Publisher's Note}

Springer Nature remains neutral with regard to jurisdictional claims in published maps and institutional affiliations.
Ready to submit your research? Choose BMC and benefit from:

- fast, convenient online submission

- thorough peer review by experienced researchers in your field

- rapid publication on acceptance

- support for research data, including large and complex data types

- gold Open Access which fosters wider collaboration and increased citations

- maximum visibility for your research: over $100 \mathrm{M}$ website views per year

At BMC, research is always in progress.

Learn more biomedcentral.com/submissions 